\title{
MEASUREMENTS ON THE SKIN CAPILLARIES IN CASES OF POLYCYTHEMIA VERA AND THE RÔLE OF THESE CAPILLARIES IN THE PRODUCTION OF ERYTHROSIS
}

\author{
GEORGE E. BROWN AND CHARLES SHEARD
}

(From the Division of Medicine and Section on Physics, Mayo Clinic and The Mayo Foundation, Rochester, Minnesota)

(Received for pubication March 8, 1926)

\section{INTRODUCTION}

One of the outstanding features of polycythemia vera is the color of the skin. Clinical descriptions employ the terms brick red, congestive facies, cyanosis and erythrosis. Vaquez, who reported the first observed case of this disease, noted cyanosis as the prevailing tint. Osler thought that the color change was not that of cyanosis but congestion or redness. Since the microscopic investigation of the skin capillaries has shown definite and measurable variation of these vessels in this disease, it seemed to us that a quantitative analysis of the blood and vascular factors would add much to an adequate understanding of the color changes, and herewith report the results of such analysis.

The color of the skin in cases of polycythemia vera is predominately red but subject to marked variations. The redness affects largely the facial and acral regions; the hands to the glove line, and the face and neck to the décolleté margin. The feet are usually less red than the hands. The mucous membranes appear cyanotic when the skin is definitely red. Cyanosis has not been observed in the conjunctiva; this tissue has a bright red, or an injected or inflamed appearance. On the trunk and proximal portions of the extremities color changes are much less than on the more distal and facial areas. The skin over the trunk and back may have the mild flushed appearance of a scarlatiniform rash.

Clinical descriptions of the color of the skin in our cases by various co-workers were "markedly red," "brick red," "reddish cyanosis," and 
"markedly cyanotic." Observation of the color by different or by the same observers have shown variations during the same, and on different, days. Redness is common during the warmer months, and cyanosis during the colder months. In the cool period of early morning, cyanosis is more marked, and at mid-day, less marked. Age and sex seems to play a part. Younger persons are less cyanosed than older ones, and it seemed as if females were less cyanotic than males. In brief, the color of the skin in cases of polycythemia vera in the acral and facial areas, is that of erythrosis, with a marked tendency toward cyanosis.

\section{COMPONENTS OF SKIN COLOR}

The color of the normal Caucasian skin is a complex composite of several factors, and subject to many variations incident to environmental, psychic, and postural influences. In attempting to differentiate the various components the following are the most important data.

The major factor is the blood content of the vessels of the skin, which is affected by the following variable factors: (1) the absolute amount of circulating cells and hemoglobin, and (2) area of exposure of the capillary blood, which depends on the number of open capillaries for each unit of surface area and the area of the exposed portion of the capillary loops; the minor factors are (1) the thickness and pigment content of the epidermis; (2) the color of the plasma, as in jaundice; (3) variations in the oxygen unsaturation of the capillary blood, and (4) color effects of the superficial venules.

For estimating the relative importance of the major and minor factors, very little information is available other than that from the blood. There is no available information on the capillaries, and the thickness and color values of the epidermis, the latter of which may become of major importance, as in Addison's disease. Pigmentation is not an outstanding features of polycythemia vera, although the effect of weather exposure with tanning undoubtedly is of some importance in determining the areas of greatest erythrosis.

Quantitative estimations of the color of the plasma can be obtained by determining the bilirubin content of the blood serum. When this substance has a concentration of about $5 \mathrm{mg}$. or more for each $100 \mathrm{cc}$. of plasma, jaundice is recognizable in the tissues. 
The amount of the oxygen unsaturation of the capillary blood determines the presence of cyanosis. Lundsgaard and Van Slyke have shown that a normal range of venous oxygen unsaturation in a patient with polycythemia vera is 5 to 6.6 per cent by volume. Cyanosis becomes visible in the skin when the mean oxygen unsaturation of the capillary blood is in excess of 6 per cent by volume. They attribute the marked tendency toward cyanosis to two conditions: the increased content of hemoglobin, which magnifies the existing oxygen unsaturation; and the abnormal condition of the capillaries as relating to changes in number and width. The rate of capillary flow is probably an important factor.

The part played by the superficial venules in producing the color of the skin is not known. Goldschmidt and Light have shown a type of cyanosis, not related to oxygen unsaturation and probably due to increased peripheral venous pressure. ${ }^{1}$ This form of cyanosis is observed with the hand in the pendent position and is relieved by eleration.

\section{METHODS OF INVESTIGATION}

Studies were carried out tc determine: (1) the average number of capillary loops for each square millimeter of skin in normal persons and in patients with polycythemia vera, (2) the relationship of the number and area of open capillaries to the total blood and hemoglobin volumes, and (3) the ratio of the total area of exposed capillary blood to each square millimeter of skin surface.

Five patients presenting the typical clinical syndrome of polycythemia vera were observed. The spleen and liver were enlarged in all. The blood volume, number of erythrocytes and percentage of hemoglobin showed the large increases typical of this disease.

The total circulating cell, plasma and hemoglobin volumes were determined by the dye method, according to the technic described by Keith, Rowntree, and Geraghty, except that Congo-red instead of vital red dye was employed. The total circulating hemoglobin was determined by multiplying the total circulating blood volume by the grams percentage of hemoglobin. The hemoglobin was determined by

${ }^{1}$ We have obtained increased values for oxygen unsaturation of the arterial blood in one case.

THE JOLRNAL OF CLINICAL INVESTIGATION, vol. II. No. 5 
the acid hematin method, using the permanent standard of Haden. ${ }^{2}$ The nail-fold capillaries were examined by the Lombard method. The technical details have been described in former papers. Instantaneous photomicrographs (Sheard's technic) of the capillaries, the nail-fold vessels and skin over first and second joints were made (figs. 1 and 2). The films were projected on a screen and a total magnification of 750 diameters was obtained. The irregular areas,

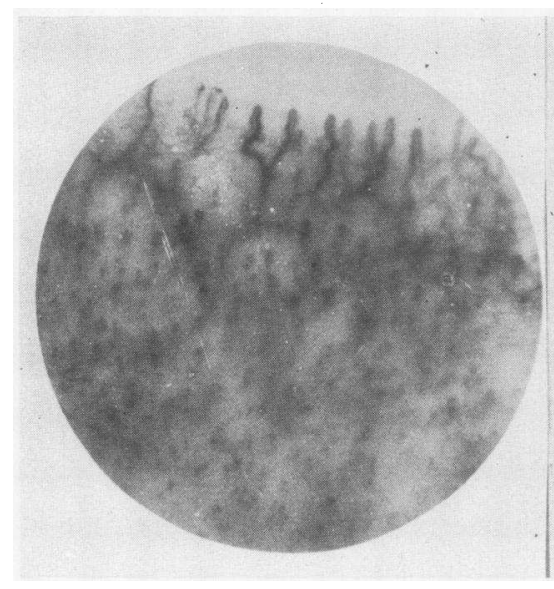

FIG. 1

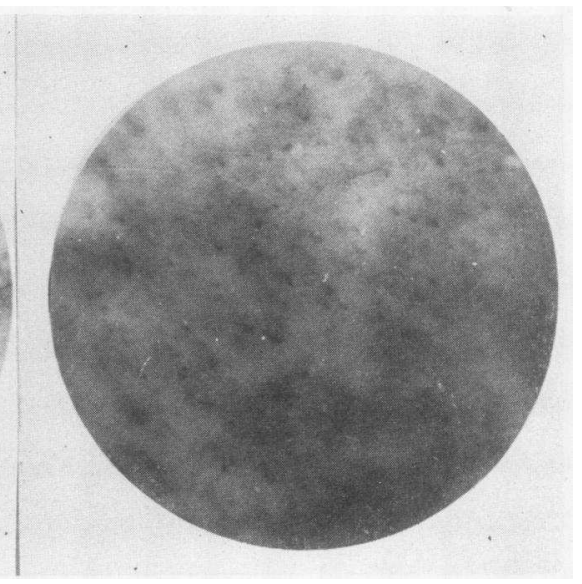

FIG. 2

Fig. 1. Photomicrograph of Skin Capillaries at the NaIl-fold in a Young Normal SubJect ${ }^{3}$

Note the collecting venules and capillary bed $(\times 25)$. Time of exposure onetenth second.

Fig. 2. Photomicrograph of Capillary Tops in the Skin in the First Joint in the Same Person as in Figure $1(\times 25)$

Time of exposure one-eighth second

representing the capillary areas or exposed capillary blood, were traced on paper and the dimensions obtained by the use of a planimeter.

The total area of the exposed capillary blood was computed by obtaining the average of ten such areas and multiplying by the average number of open capillaries for each square millimeter of skin area.

${ }^{2}$ Fifteen and six-tenths grams of hemoglobin for each $100 \mathrm{cc}$. of blood was taken as the normal, 100 per cent.

${ }^{3}$ All photomicrographs reproduced in this paper are made from the original untouched negatives. 
TABLE 1

Measurements of the capillaries of the skin in cases of polycythemia vera and of controls*

\begin{tabular}{|c|c|c|c|c|c|c|c|}
\hline Case & Age & Sex & Clinical diagnosis & Region examined & $\begin{array}{c}\text { Average } \\
\text { area of } \\
\text { blood visi- } \\
\text { ble in } \\
\text { capillary, }, \\
\text { sq. mm. }\end{array}$ & $\begin{array}{l}\text { Number of } \\
\text { capillaries } \\
\text { visible in } \\
\text { each square } \\
\text { millimeter }\end{array}$ & $\begin{array}{c}\text { Ratio of } \\
\text { area of } \\
\text { capillary } \\
\text { blood } \\
\text { exposure } \\
\text { unit (1 sq. } \\
\text { mm.), } \\
\text { skin area, } \\
\text { per cent }\end{array}$ \\
\hline 1 & 57 & M. & Polycythemia vera & $\begin{array}{l}\text { Nail-fold } \\
\text { First joint } \\
\text { Second joint }\end{array}$ & $\begin{array}{l}0.0038 \\
0.0007 \\
0.0020\end{array}$ & $\begin{array}{l}45 \\
80 \\
56\end{array}$ & $\begin{array}{r}17.0 \\
5.6 \\
11.2\end{array}$ \\
\hline 2 & 62 & M. & $\begin{array}{l}\text { Polycythemia vera mild } \\
\text { essential hypertension }\end{array}$ & $\begin{array}{l}\text { Nail-fold } \\
\text { First joint } \\
\text { Second joint }\end{array}$ & $\begin{array}{l}0.0033 \\
0.0008 \\
0.0044\end{array}$ & $\begin{array}{l}52 \\
85 \\
46\end{array}$ & $\begin{array}{r}17.2 \\
6.8 \\
20.2\end{array}$ \\
\hline 3 & 58 & M. & $\begin{array}{l}\text { Polycythemia vera, } \\
\text { severe hypertension }\end{array}$ & $\begin{array}{l}\text { Nail-fold } \\
\text { First joint } \\
\text { Second joint }\end{array}$ & $\begin{array}{l}0.0041 \\
0.0021 \\
0.0030\end{array}$ & $\begin{array}{l}40 \\
70 \\
65\end{array}$ & $\begin{array}{l}16.4 \\
14.7 \\
19.5\end{array}$ \\
\hline 4 & 37 & F. & Polycythemia vera & $\begin{array}{l}\text { Nail-fold } \\
\text { First joint } \\
\text { Second joint }\end{array}$ & $\begin{array}{l}0.0036 \\
0.0013 \\
0.0018\end{array}$ & $\begin{array}{l}42 \\
65 \\
88\end{array}$ & $\begin{array}{r}15.1 \\
8.5 \\
15.8\end{array}$ \\
\hline 5 & 52 & M. & Polycythemia vera & $\begin{array}{l}\text { Nail-fold } \\
\text { First joint } \\
\text { Second joint }\end{array}$ & $\begin{array}{l}0.0052 \\
0.0012 \\
0.0048\end{array}$ & $\begin{array}{r}38 \\
108 \\
50\end{array}$ & $\begin{array}{l}19.8 \\
12.9 \\
24.0\end{array}$ \\
\hline \multicolumn{5}{|c|}{ Average values. } & 0.0028 & 62 & 15.0 \\
\hline & 26 & F. & Normal & $\begin{array}{l}\text { Nail-fold } \\
\text { First joint } \\
\text { Second joint } \\
\text { Nail-fold } \\
\text { First joint } \\
\text { Second joint }\end{array}$ & $\begin{array}{l}0.0031 \\
0.0007 \\
0.0008 \\
0.0021 \\
0.0005 \\
0.0009\end{array}$ & $\begin{array}{l}25 \\
38 \\
50 \\
\\
42 \\
40 \\
53\end{array}$ & $\begin{array}{l}7.7 \\
2.7 \\
4.0 \\
\\
8.4 \\
2.0 \\
4.8\end{array}$ \\
\hline & & & & & 0.0013 & 41 & 4.9 \\
\hline
\end{tabular}

* All data are from the right hand.

$\dagger$ Five to 10 areas averaged in each.

The ratio of the area of the capillary blood exposure to a unit area of skin (1 sq. mm.) was calculated.

A slight error exists in this type of investigation, because of the 
shifting of the number of open capillaries in the skin and irregularities in the areas measured. A series of comparative photomicrographs of the same area taken over a short period of time under controlled conditions showed only a slight variation in the number of open vessels. There are also a number of capillary loops in the deeper layer of the epidermis which are not visable but probably play a part in determining the color of the skin. The venules likewise contribute to the color, but we could not convince ourselves just how important they are.

TABLE 2

Blood and capillaries in cases of polycythemia vera

\begin{tabular}{|c|c|c|c|c|c|c|c|c|c|c|c|}
\hline \multirow[b]{2}{*}{ త్ర } & \multicolumn{2}{|c|}{ Hemoglobin } & \multirow[b]{2}{*}{ 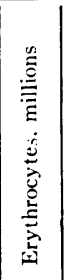 } & \multicolumn{2}{|c|}{ Blood } & \multicolumn{2}{|c|}{ Plasma } & \multirow{2}{*}{ 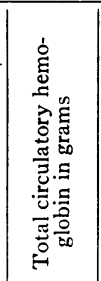 } & \multirow{2}{*}{ 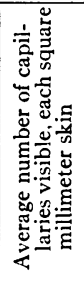 } & \multirow{2}{*}{ 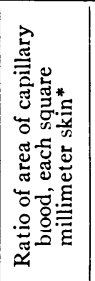 } & \multirow[b]{2}{*}{ Color of skin } \\
\hline & 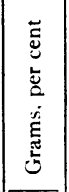 & 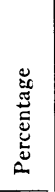 & & 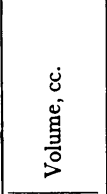 & 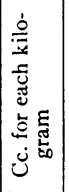 & $\begin{array}{l}\dot{0} \\
\stackrel{0}{0} \\
\text { छे } \\
=\end{array}$ & 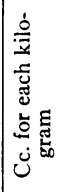 & & & & \\
\hline 1 & 26.0 & 171 & 7.00 & 14,700 & 180 & 3,670 & 46 & 3,700 & 62 & 12 & $\begin{array}{l}\text { Marked erythrosis } \\
\text { with cyanosis }\end{array}$ \\
\hline 2 & 24.5 & 161 & 5.02 & 8,580 & 136 & 3,430 & 54 & 2,100 & 61 & 15 & Mild erythrosis \\
\hline 3 & 31.1 & 195 & 7.00 & 12,400 & 213 & 3,600 & 62 & 3,850 & 98 & 19 & $\begin{array}{l}\text { Marked erythrosis } \\
\text { and cyanosis }\end{array}$ \\
\hline 4 & 19.0 & 125 & 6.90 & 7,700 & 167 & 2,250 & 48 & 1,490 & 65 & 14 & Mild erythrosis \\
\hline 5 & 23.4 & 153 & 6.12 & 11,000 & 173 & 5,300 & 52 & 2,590 & 60 & 17 & $\begin{array}{l}\text { Moderate ery- } \\
\text { throsis }\end{array}$ \\
\hline & 15.6 & 100 & 4.50 & $5,100 \dagger$ & 85 & $3,000 \dagger$ & 50 & 800 & 41 & 4.9 & $\begin{array}{l}\text { Average normal } \\
\text { values }\end{array}$ \\
\hline
\end{tabular}

* Per cent.

† Calculated for a person with body weight of $60 \mathrm{~kg}$.

On the microscopic examination of the skin of many patients the color between capillaries is very light, whereas that of patients with other diseases, especially polycythemia vera, shows a pinkish tint in the deeper layers. There is no doubt, however, that the greatest amount of color is contributed by the capillary blood.

The intensity of the cyanosis varied according to the environmental temperature. The average number of open capillaries in cases of polycythemia vera varied from 38 to 108 for each unit area of skin, averaging 62 (table 1). We were not able to demonstrate 
any marked variation in the number of capillaries in the same subject. The conditions of the examination were quite comparable.

An average of 41 loops (range 25 to 53) for each unit area of skin was found in the normal subjects (table 1). The average area of the capillary summit, or the area of exposed capillary blood, in the patients

TABLE 3

The effect of the reduction of the blood on the area and number of capillaries in cases of polycythemia vera

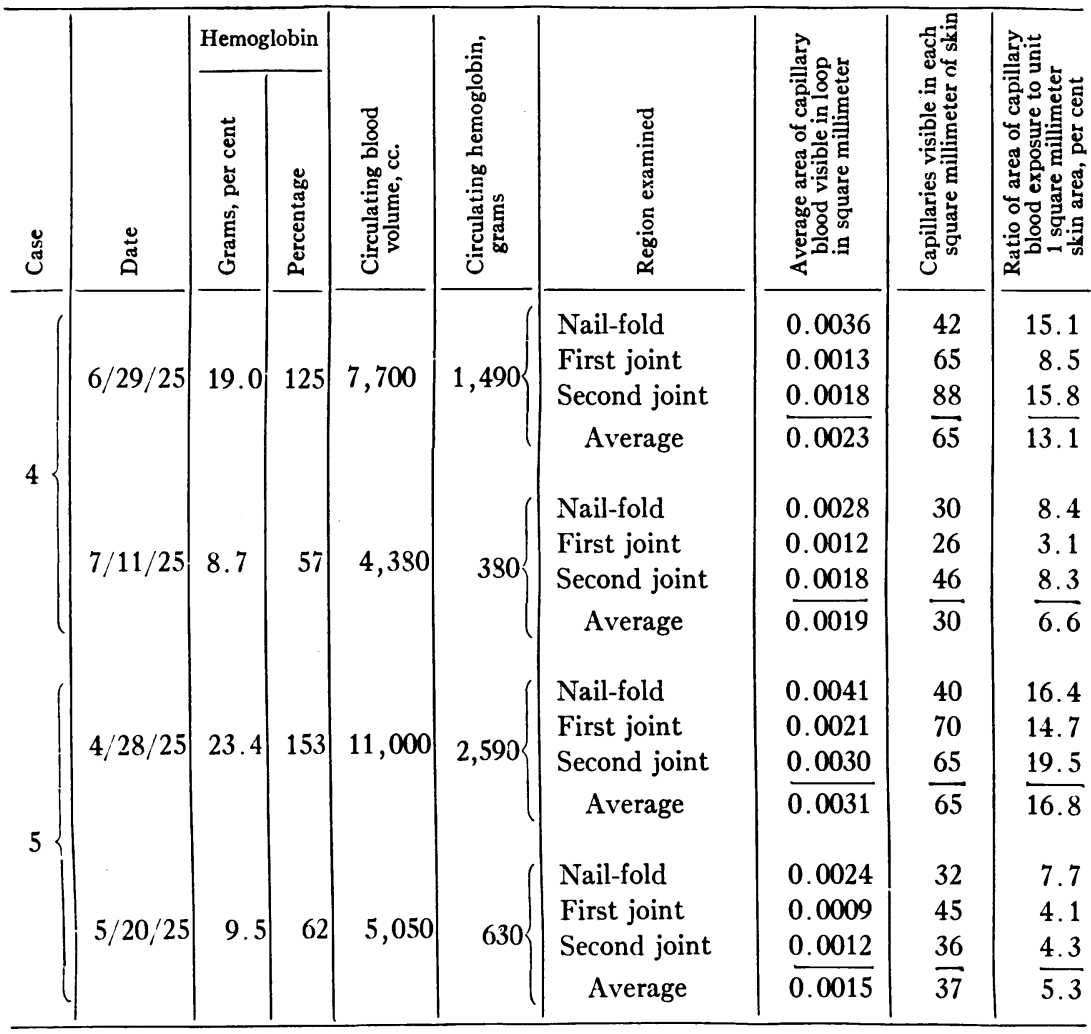

with polycythemia vera was $0.0028 \mathrm{sq} . \mathrm{mm}$. This is more than twice the area $(0.0013)$ found in the normal subjects.

The ratio of the total area of exposure of the capillary blood to each square millimeter of skin surface averaged 15 per cent in the cases of polycythemia vera (table .1). This is three times greater than for 


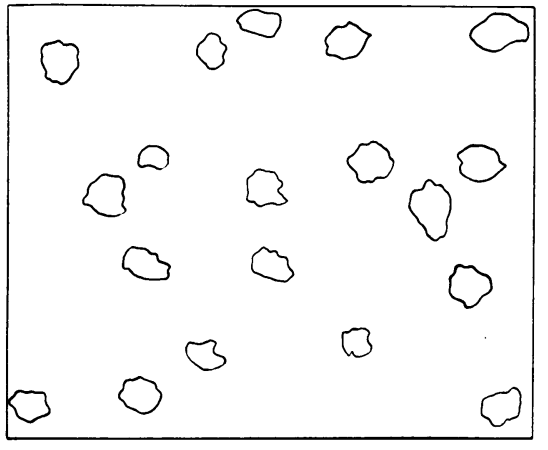

FIG. 3

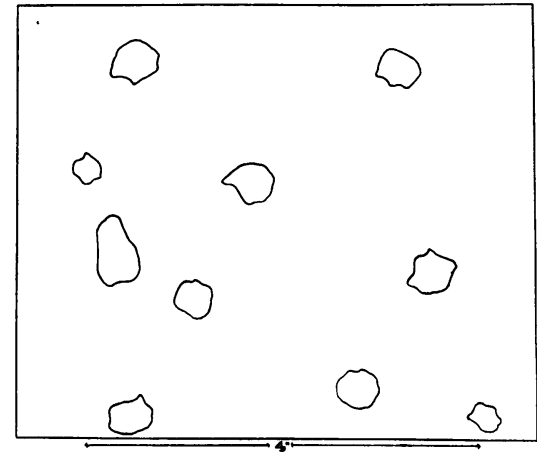

FIG. 4

Fjg. 3. Sketch of Blood Areas in Capillary Tops in a Case of Polycythemia Vera, First Joint, before Treatment. $\times 750$ (Reduced $\frac{1}{3}$ )

Fig. 4. Sketch of Blood Areas in Capillary Tops in the Same Region of the Skin as in Figure 3, after Treatment. $\times 750$ (Reduced $\frac{1}{3}$ )

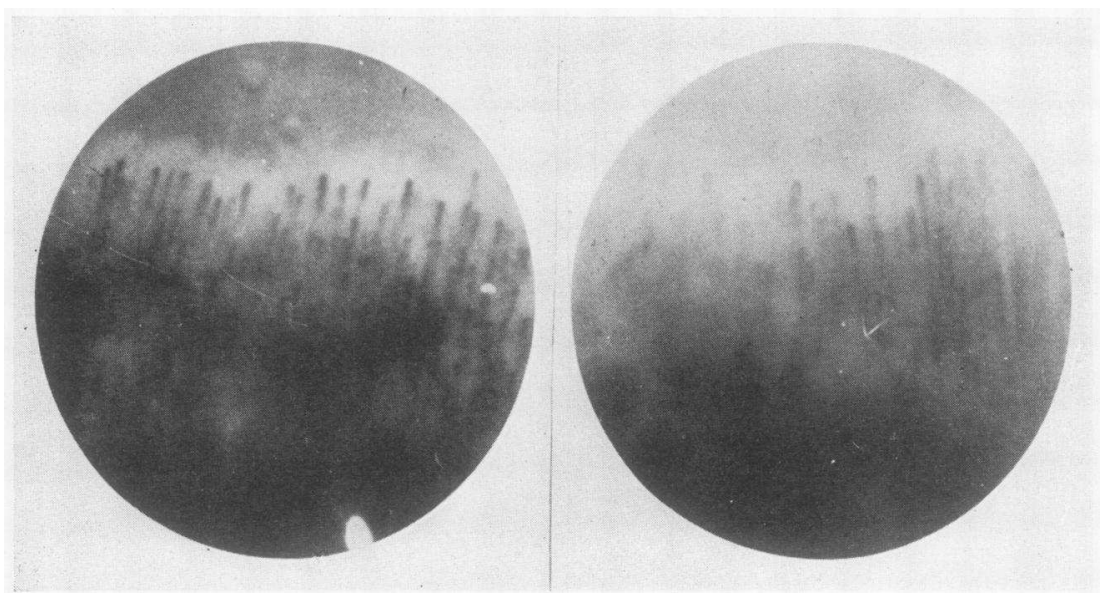

FIG. 5

FIG. 6

Fig. 5. Photomicrograph of the Skin Capillaries at the NaIl-Fold in Case of Polycythemia Vera, before Treatment. $\times 25$

Time of exposure one-tenth second

Fig. 6. Photomicrograph of the Skin Capillaries at the Nailfold in Case. of Polycythemia Vera, Same Skin Region and Same Finger as in

Figure 5, after Treatment. $\times 25$

Time of exposure one-tenth second 
normal subjects (4.9 per cent). The area of greatest capillary blood exposure was found in the nail-folds and the skin near the second joint.

There is no constant relationship or parallelism between the degree of increased volume of the blood and the number of open capillaries (table 2). The relationship was fairly constant between the area of exposed capillary blood and the blood and hemoglobin volume. In Case 3 is shown the greatest increase in the volume of the blood per

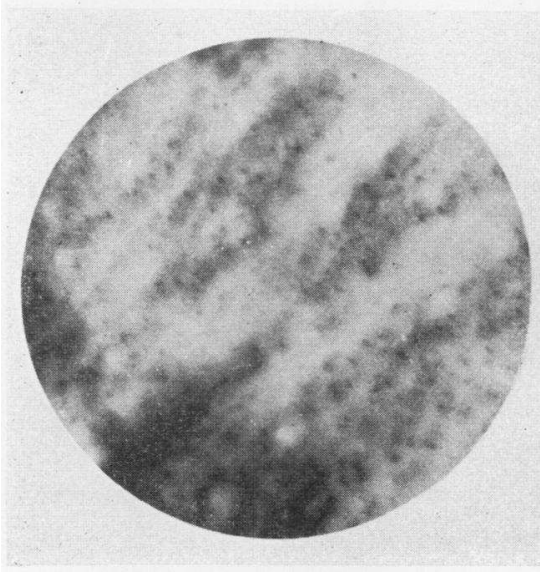

FIG. 7

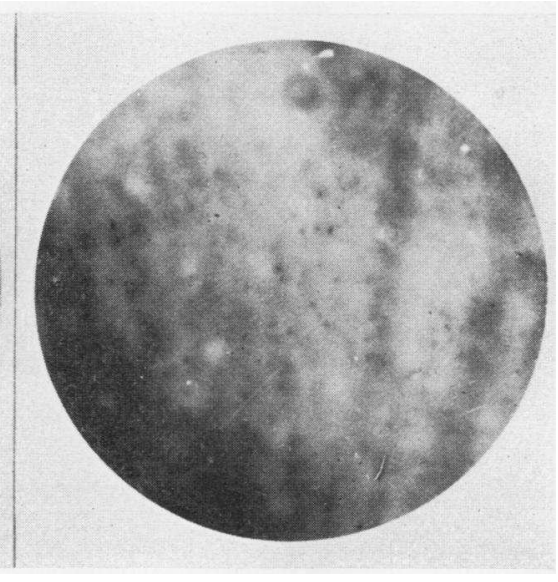

FIG. 8

Fig. 7. Photomicrograph of the Capillary Tops in Case of Polycythemia Vera, Skin Area in Region of First Joint, before Treatment. $\quad \times 25$

Time of exposure one-tenth second

Fig. 8. Photomicrograph of the Capillary Tops in Case of Polycythemia Vera, Same Skin Area and Same Finger as in Figure 7, after TREATMENT. $\times 25$

Time of exposure one-eighth second

kilogram and hemoglobin with the greatest number of open capillaries and the greatest ratio of capillary blood exposure to each square millimeter of skin.

The capillary and blood factors before and after reduction of the blood volume by treatment with phenylhydrazin have been studied (figs. $3,4,5,6,7$ and 8 ). In Case 4 (table 3 ), the ratio of the total area of exposed capillary blood to each square millimeter of skin was 13.1 per cent and the average area of visible capillary blood in each 
loop was $0.0023 \mathrm{sq} . \mathrm{mm}$. The average number of loops was sixty-five for each square millimeter of skin area. The blood volume was reduced to $4,380 \mathrm{cc}$. and circulating hemoglobin to 380 grams. The ratio of the area of the exposed capillary blood to a unit area of skin diminished to 6.6 per cent and the average number of loops to thirty, while the average area of the visible capillary blood diminished to 0.0019 sq. $\mathrm{mm}$. In Case 5 (table 3 ) the blood volume was reduced by treatment. The ratio of the total area of the exposed capillary blood to unit area of skin decreased from 16.8 to 5.3 per cent. The number of loops and the average area of the visible capillary in each loop decreased one-half.

\section{DISCUSSION}

The color of the skin in cases of polycythemia vera is due largely to one primary factor, the large increase in the circulating cells and hemoglobin; and two modifying factors, the number of capillaries for each unit area of skin and the area of capillary blood exposed in each capillary. The circulating cell volume, according to the dye method, is increased approximately 75 to 100 per cent above the average normal. As a result of the large increase in the blood volume the capillary bed of the skin assumes a storage function. As has been shown, this involves chiefly the venous segment, which portion extends well over on the arterial side of the loop. Proximal to the nail-fold area the skin capillaries are arranged at right angles to the skin surface, so that only the summits or crests of the loops are visible but this portion is distended and its area is measurably enlarged. The area of the capillary crest was approximately double that in normal subjects.

Further accommodation for the increase in blood volume is made by an increase in the number of open capillaries. Our data show an average of sixty-two loops for each square millimeter of skin area in cases of polycythemia vera, as compared to forty-one in normal subjects, an increase of 50 per cent. The ratio of the area of exposure of capillary blood to each square millimeter of skin was found to be three times greater than in normal skin. These data indicate that capillary distention is more important than numerical increase in the number of loops; this is further emphasized by the effect of blood reduction on the size and number of capillary loops. 
The increase in the capillary measurements exceeds the increase in the blood elements; thus the capillary factors in the production of erythrosis are apparently the most important, although their variations are of course dependent on the augmentation of the blood volume.

The response of the capillaries to the reduction in the cell volume following treatment varied somewhat in the two cases studied. In both, the greatest change occurred in the number of open capillaries, which was reduced about 50 per cent.

It is difficult to determine the importance of the venules in the production of erythrosis in cases of polycythemia vera. These vessels are not clearly visable but contribute somewhat to the color of the skin as the tissue has a pinkish tinge between the capillary loops. The superficial venules of the cheek and nose are dilated in a few patients, especially those subject to exposure to the wind and sun. The areas of venous dilatation show cyanosis to a marked degree, as would be expected.

\section{SUMMARY}

The large increase in the circulating volume of erythrocytes in cases of polycythemia vera produces distention of the blood vessels, the venous vessels assuming the larger portion of this increase. The capillaries of the skin become distended, more markedly in their venous portion; and additional capillaries are formed. These changes have been studied quantitatively by photomicrographic methods, and compared to similar data obtained from normal subjects. The ratio of the total area of visible capillary blood to a unit area of skin is determined and found to be definitely increased. The demonstrable increase in the size and number of the capillaries exceeds the changes in the blood. There is a gradual decrease in the size and number of capillaries with reduction of the cell volume.

\section{BIBLIOGRAPHY}

1. Brown, G. E., and Giffin, H. Z.: Amer. Jour. Med. Sci., 1926, clxxi, 157-168. Studies of the Vascular Changes in Cases of Polycythemia Vera.

2. Goldschmidt, S., and Light, A. B.: Amer. Jour. Physiol., 1925, lxxiii, 173192. A Cyanosis, Unrelated to Oxygen Unsaturation, Produced by Increased Peripheral Venous Pressure. 
3. Haden, R. L.: Jour. Lab. and Clin. Med., 1923, viii, 411-414. A Method for the Determination of Hemoglobin.

4. Keith, N. M., Rowntree, L. G., and Geraghty, J. T.: Arch. Int. Med., 1915, xvi, 547-576. A Method for the Determination of Plasma and Blood Volume.

5. Lombard, W. P.: Amer. Jour. Physiol., 1911-1912, xxix, 335-362. The Blood Pressure in the Arterioles, Capillaries, and Small Veins of the Human Skin.

6. Lundsgaard, C., and van Slyke, D. D.: Cyanosis. Baltimore, The Williams \& Wilkins Co., 1923, 80 pp.

7. Osler, William: Amer. Jour. Med. Sci., 1903, cxxvi, 187-201. Chronic Cyanosis, with Polycythemia and Enlarged Spleen. A New Clinical Entity.

8. Sheard, Charles: Science, 1924, 1x, 409-410. Instantaneous Photomicrography of the Skin Capillaries of the Living Human Body.

9. Sheard, C., and Brown, G. E.: Jour. Lab. and Clin. Med., 1925, x, 925-929. A Method for Instantaneous Photomicrography of the Skin Capillaries.

10. Vaquez, H.: Comp. rend. Soc. de biol., 1892, iv, s. 9, 384-388. Sur une forme spéciale de cyanose s'accompagnant d'hyperglobulie excessive et peristante. 